\title{
Road safety legislation in the Americas
}

\author{
Martha Hijar, ${ }^{1}$ Ricardo Pérez-Núñez, ${ }^{2}$ Cristina Inclán-Valadez, ${ }^{3}$ \\ and Eugênia Maria Silveira-Rodrigues ${ }^{4}$
}

Suggested citation Hijar M, Pérez-Núñez R, Inclán-Valadez C, Silveira-Rodrigues EM. Road safety legislation in the Americas. Rev Panam Salud Publica. 2012;32(1):70-6.

\begin{abstract}
Legislating five of the main risk factors for road traffic injuries (RTIs), as much as enforcing the law, is essential in forging an integral culture of road safety. Analysis of the level of progression in law enforcement allows for an evaluation of the state of world regions. A secondary analysis of the 2009 Global status report on road safety: time for action survey was undertaken to evaluate legislation on five risk factors (speed management, drinking and driving, motorcycle helmet use, seatbelt use, and use of child restraints) in the Americas. Laws were classified depending on their level of progression: the existence of legislation, whether the legislation is adequate, a level of law enforcement $\geq 6$ (on a scale of 0-10), and whether the law is considered comprehensive. A descriptive analysis was performed. The totality of the countries has national or subnational legislation for at least one of the five risk factors. However, $63 \%$ have laws on the five risk factors studied, and none of them has comprehensive laws for all five. Seatbelt use appears to be the most extended enforced legislation, while speeding laws appear to be the least enforced. There are positive efforts that should be recognized in the region. However, the region stands in different stages of progression. Law enforcement remains the main issue to be tackled. Laws should be based on evidence about what is already known to be effective.
\end{abstract}

Key words Legislation as topic; accidents, traffic; seat belts; child restraint systems; head protective devices; Americas.

The world report on prevention of road traffic injuries (RTIs) launched in 2004 by the World Health Organization (WHO) highlighted the importance of enacting appropriate legislation to address the use of seatbelts and child restraints, the wearing of motorcycle and bicycle helmets, alcohol-impaired driving, and speeding. The need to enforce such laws was also emphasized as one of

\footnotetext{
1 Instituto Nacional de Salud Pública, Centro de Investigación en Salud Poblacional, Cuernavaca, Morelos, México.

2 Instituto Nacional de Salud Pública, Centro de Investigación en Sistemas de Salud, Cuernavaca, Morelos, México. Send correspondence to: Ricardo Pérez-Núñez, ricardo.perez@insp.mx

3 LSE Cities, London School of Economics and Political Science, London, United Kingdom.

4 Pan American Health Organization, Sustainable Development and Environmental Health Area, Washington, D.C., United States of America.
}

the main recommendations of the world report. It was concluded that legislation on the main risk factors for RTIs and its accurate applicability are essential for developing an integral culture of road safety (1). These factors require a comprehensive approach to improve road safety and to decrease the high burden that RTIs represent for the entire world.

During the same year, the Pan American Health Organization (PAHO) assessed road safety legislation in 20 countries of the Americas region (2). At that time, legislation on seatbelts, child restraints, helmet use, and drinking and driving was studied. Speed limit legislation was not addressed. One of the main recommendations of the study was that, in some cases, legislation should be based on solid evidence, well orga- nized, and updated. It was realized that many countries have different laws at the national, state, and municipal levels regarding risk factors for RTIs, which could be counterproductive. Around the region, a lack of legislation meeting what has been found to be effective for seatbelts and child restraints was highlighted (2).

To follow up on its recommendations and to better assess the status of road safety in the world from a comprehensive approach, during 2008 WHO developed and implemented a global survey that was answered by 178 countries. Before this effort, comparison among countries was difficult, because standardized data were not available. Furthermore, without this information it was not possible to evaluate the extent to which the 
comprehensive approach recommended by WHO is being implemented by countries (3). PAHO led this effort for the region of the Americas and published a regional report with the main results of this global survey for the countries of the region (4). The objective of the present study is to perform an in-depth analysis of the level of progression of road safety legislation in the Americas. Analysis of the level of progression in law enforcement allows for evaluation of the state of the region in a positive and realistic way, highlighting the region's assets and gaps in this important public health problem.

\section{MATERIALS AND METHODS}

\section{Design and study population}

A secondary analysis of the 2009 Global status report on road safety: time for action survey (GRSS) was carried out (3). This survey had the objective of assessing the status of road safety in all WHO member states to detect potential gaps in road safety and then help countries to identify key priorities for intervention. Indirectly, this survey also evaluated the extent to which countries had followed the recommendations of the world report on RTI prevention published by WHO in 2004 (1).

Although 178 countries answered the world survey, this analysis focuses on the 30 of the 34 member states from the region of the Americas, one associate member state (Puerto Rico), and one invited country (British Virgin Islands) that participated in this global initiative. Antigua and Barbuda, Dominica, Grenada, Haiti, and Saint Kitts and Nevis did not participate. This number represents $88 \%$ of the countries in the region but accounts for $99 \%$ of the population living in the Americas. The GRSS in the Americas was conducted beginning in May 2008 and was completed in September 2008 (4).

\section{Data collection and conformation of variables}

The GRSS consisted of a self-administered questionnaire that was sent to all participant countries. To lead this effort, national data coordinators in each country were identified and then trained by PAHO specialists to standardize application of the survey. National data coordinators were asked to involve in the survey up to eight local experts from the health, transport, and enforcement sectors among nongovernmental organizations, academics, and other road safety practitioners. Each respondent was asked to complete the questionnaire independently and then to discuss each of the answers at a consensus meeting. In Puerto Rico and Saint Vincent and the Grenadines, the questionnaire was completed only by the national data coordinator taking into consideration the survey filled by the people involved. A final country response was then submitted to PAHO. In order to solve and elucidate any inconsistencies, information was integrated into a database that was further validated by establishing a dialog between PAHO representatives and the national data coordinator to resolve any inconsistencies. This information was then sent for government approval. More detailed information on the methodology has been published elsewhere (5).

The applied questionnaire mainly explored the availability of legislation on five behavioral risk factors: speeding, drinking and driving, motorcycle helmet use, seatbelt use, and use of child restraints. The perception of enforcement levels related to each legislation was also evaluated on a scale of $0-10$. These grades were the result of a consensus among all local respondents. For this analysis, laws were classified on a scale, depending on their level of progression, using the following criteria: existence of a specific law tied to the corresponding risk factor; existence of a specific law and whether it was adequate; existence of a specific law and whether it was enforced (a subjective threshold of $\geq 6$, taking as reference the reported perception of enforcement, was used); and if the law was considered comprehensive, a combination of the existence of the law, its adequacy, and a high level of enforcement $(\geq 6)$ (see Table 1). This work set the cut-off point at 6 to define adequate enforcement of laws for two reasons. The first was that only a few countries in the region reported enforcement $>7$ for any of the five laws [cut-off point defined by WHO in the GRSS (3)]. The second reason was that the number 6 represents the minimum approbatory score as it is above the halfway point of 5 .

Adequacy of laws was defined by specific recommendations of WHO based on what has been found to be effective in terms of injury prevention (1). It has been widely accepted that countries need to set speed limits that reflect the function of individual roads, notably in urban areas where speed limits should not exceed $50 \mathrm{~km} / \mathrm{h}$; blood alcohol concentration (BAC), or the equivalent breath alcohol content limits, should be $0.05 \mathrm{~g}$ / $\mathrm{dL}$ or less; helmet laws should cover all riders who are legally allowed to ride on motorized two- or three-wheelers, all engine types, and all road types, and helmets should meet national or international standards; and seatbelts should be used by front- and rear-seat occupants of all vehicles.

\section{Analysis}

A descriptive analysis was performed; central tendency and dispersion measures were calculated for continuous variables (mean, maximum, and minimum values) as well as frequencies and percentages for categorical variables using Stata 10.1 (6).

\section{RESULTS}

As can be seen in Figure 1, 63\% of the countries under study had laws for the five risk factors studied, and only Bolivia did not have legislation for two risk factors. On the other hand, $60 \%$ of the countries had no comprehensive laws for any of the five risk factors, with Canada, Brazil, and Barbados addressing the most risk factors: three each. Figure 2 shows the level of progression of these five risk factors in the Americas region. Results are presented separately by risk factor.

\section{Speeding}

Table 2 indicates that the 30 countries have national legislation on speeding, and two countries (United States of America and Canada) have legislation set at the subnational level. In Canada all subnational legislation sets speed limits at $70 \mathrm{~km} / \mathrm{h}$, but in the United States the limit varies across states. However, this legislation is adequate in only three countries (9.4\%): Honduras, Nicaragua, and Paraguay. Legislation in $63 \%$ of the countries established that speed limits on urban roads should not exceed $50 \mathrm{~km} / \mathrm{h}$. Local decision makers have the authority to reduce these national speed limits in $28 \%$ of the countries evaluated. On average, enforcement of 
TABLE 1. Criteria for classifying laws depending on their level of progression

\begin{tabular}{|c|c|c|c|c|}
\hline Risk factor & Existence & Adequacy & Enforcement & Comprehensive law \\
\hline Speeding & $\begin{array}{l}\text { Legislation regulating } \\
\text { speed limits }\end{array}$ & $\begin{array}{l}\text { Speed limit not exceeding } 50 \mathrm{~km} / \mathrm{h} \\
\text { Legislation gives provincial or local } \\
\text { decision makers the authority to } \\
\text { reduce these national speed limits. }\end{array}$ & $\begin{array}{l}\text { Law is reported to be } \\
\text { enforced at a value of } 6 \text { or } \\
\text { more (on a scale of } 0-10 \text { ). }\end{array}$ & $\begin{array}{l}\text { Countries with speed limits on urban roads not } \\
\text { exceeding } 50 \mathrm{~km} / \mathrm{h} \text { that give provincial or local } \\
\text { decision makers the authority to reduce these national } \\
\text { speed limits and that report enforcement at a value of } \\
6 \text { or more (on a scale of } 0-10 \text { ) }\end{array}$ \\
\hline $\begin{array}{l}\text { Drinking } \\
\text { and driving }\end{array}$ & $\begin{array}{l}\text { Legislation on drinking } \\
\text { and driving }\end{array}$ & $\begin{array}{l}\text { Use of BAC limit of less than or } \\
\text { equal to } 0.05 \mathrm{~g} / \mathrm{dL} \\
\text { BAC limit for young or novice } \\
\text { drivers set lower than limit for } \\
\text { general population. }\end{array}$ & $\begin{array}{l}\text { Law is reported to be } \\
\text { enforced at a value of } 6 \text { or } \\
\text { more (on a scale of } 0-10 \text { ). }\end{array}$ & $\begin{array}{l}\text { Countries with legislation on drinking and driving that } \\
\text { use a BAC limit of less than or equal to } 0.05 \mathrm{~g} / \mathrm{dL} \text { that } \\
\text { set a BAC limit for young or novice drivers lower than } \\
\text { limit for general population and report enforcement at a } \\
\text { value of } 6 \text { or more (on a scale of } 0-10 \text { ) }\end{array}$ \\
\hline Helmet use & $\begin{array}{l}\text { Legislation on helmet } \\
\text { use }\end{array}$ & $\begin{array}{l}\text { Helmets to be worn by all } \\
\text { passengers of all ages } \\
\text { For all engine types of motorized } \\
\text { two wheelers } \\
\text { On all roads } \\
\text { Helmets required to meet a specific } \\
\text { standard }\end{array}$ & $\begin{array}{l}\text { Law is reported to be } \\
\text { enforced at a value of } 6 \text { or } \\
\text { more (on a scale of } 0-10 \text { ) }\end{array}$ & $\begin{array}{l}\text { Countries with legislation that requires helmets to be } \\
\text { worn by all passengers of motorized two-wheelers, for } \\
\text { all engine types of motorcycles, on all roads; requires } \\
\text { helmets to meet a specific standard; and is reported } \\
\text { to be enforced at a value of } 6 \text { or more (on a scale of } \\
0-10 \text { ) }\end{array}$ \\
\hline $\begin{array}{l}\text { Seatbelt } \\
\text { use }\end{array}$ & $\begin{array}{l}\text { Legislation on seatbelt } \\
\text { use }\end{array}$ & $\begin{array}{l}\text { Applies to all car occupants (front- } \\
\text { and rear-seat occupants) }\end{array}$ & $\begin{array}{l}\text { Law is reported to be } \\
\text { enforced at a value of } 6 \text { or } \\
\text { more (on a scale of } 0-10 \text { ) }\end{array}$ & $\begin{array}{l}\text { Countries with national or subnational laws that apply } \\
\text { to all car occupants (front- and rear-seat occupants) } \\
\text { with a report of enforcement at a value of } 6 \text { or more } \\
\text { (on a scale of } 0-10 \text { ) }\end{array}$ \\
\hline $\begin{array}{l}\text { Use of child } \\
\text { restraints }\end{array}$ & $\begin{array}{l}\text { Legislation on use of } \\
\text { child restraints }\end{array}$ & $\mathrm{N} / \mathrm{A}$ & $\begin{array}{l}\text { Law is reported to be } \\
\text { enforced at a value of } 6 \text { or } \\
\text { more (on a scale of } 0-10 \text { ) }\end{array}$ & $\begin{array}{l}\text { Countries with national or subnational laws on the use } \\
\text { of child restraints for young children in vehicles and a } \\
\text { report of law enforcement of } 6 \text { or more (on a scale of } \\
0-10 \text { ) }\end{array}$ \\
\hline
\end{tabular}

Note: BAC: blood alcohol concentration, N/A: not applicable.

speeding laws was reported to be low, with a value of 3.7 in the region. Only Brazil, the British Virgin Islands, Costa Rica, and Panama (12.5\% of participating countries) reported enforcement to be equal to or greater than 6 on a scale of $0-10$. As a result, no country had comprehensive laws on speeding, according to the criteria used for this analysis.

\section{Drinking and driving}

The totality of countries has legislation on drinking and driving. In $31 \%$ of participating countries, the BAC limit for the general population was $0.05 \mathrm{~g} / \mathrm{dL}$ or less. Ten of the countries studied (Argentina, Brazil, Chile, Colombia, Costa Rica, El Salvador, Nicaragua, Panama, Peru, and Suriname) reported limits varying up to a maximum of $0.05 \mathrm{~g} / \mathrm{dL}$. The BAC limit in Honduras was $0.07 \mathrm{~g} / \mathrm{dL}$, while in the Bahamas, Belize, the British Virgin Islands, Canada, Ecuador, Guyana, Jamaica, Puerto Rico, Saint Lucia, Trinidad and Tobago, the United States, Uruguay, and Venezuela the BAC limit was 0.08 $\mathrm{g} / \mathrm{dL}$. Legislation in the United States as well as Paraguay and Guatemala is set at the subnational level. Although the United States reported a national BAC level, the other two countries did not report national BAC levels. Worth mentioning is that in Mexico, the BAC level is set at the subnational level.

Few countries follow WHO's recommendation of establishing BAC limits for younger or novice drivers at lower levels than for the general population. Only Canada, the United States, Puerto Rico, Brazil, and Panama reported having lower levels for these subgroups in this important risk factor. In this sense, adequate legislation on drinking and driving was present only in Brazil and Panama (6.3\% of participating countries) with BAC limits of 0.02 and $0.01 \mathrm{~g} / \mathrm{dL}$, respectively. Although the BAC limits were the same for the general population and for younger people, legislation in both countries was considered adequate as both levels do not exceed those recommended for younger drivers. These two countries also gave the level of enforcement a high rating and consequently were the only two countries with comprehensive laws. However, Costa Rica and Venezuela rated law enforcement at 6 and 7, respectively, which is high given that the average level of enforcement in the region was 3.6 for this risk factor.
Worth mentioning is that countries such as Barbados, Bolivia, Cuba, Dominican Republic, and Saint Vincent and the Grenadines used different parameters to define and measure the presence of alcohol in blood (physician certificate or breath content).

\section{Helmets}

All countries studied reported having national or subnational legislation on helmet use, but as for the previous two risk factors, adequate laws were present in only $40.6 \%$ of the countries: the Bahamas, Barbados, Brazil, Canada, Chile, Colombia, Jamaica, Mexico, Peru, Puerto Rico, Saint Vincent and the Grenadines, Trinidad and Tobago, and Venezuela. In slightly more than $48 \%$ of the countries, legislation did not require helmets to meet a recognized safety standard. In terms of the level of enforcement, only $40.6 \%$ of the countries reported having a level of 6 or more on a scale of 0-10: Barbados, Brazil, Canada, Colombia, Costa Rica, Cuba, El Salvador, Panama, Saint Lucia, Saint Vincent and the Grenadines, Suriname, Trinidad and Tobago, and Venezuela. The average law enforcement in the Americas was 
FIGURE 1. Number of laws addressed and number of comprehensive laws for the five risk factors under study in the region of the Americas, by country, 2008

Existence of laws

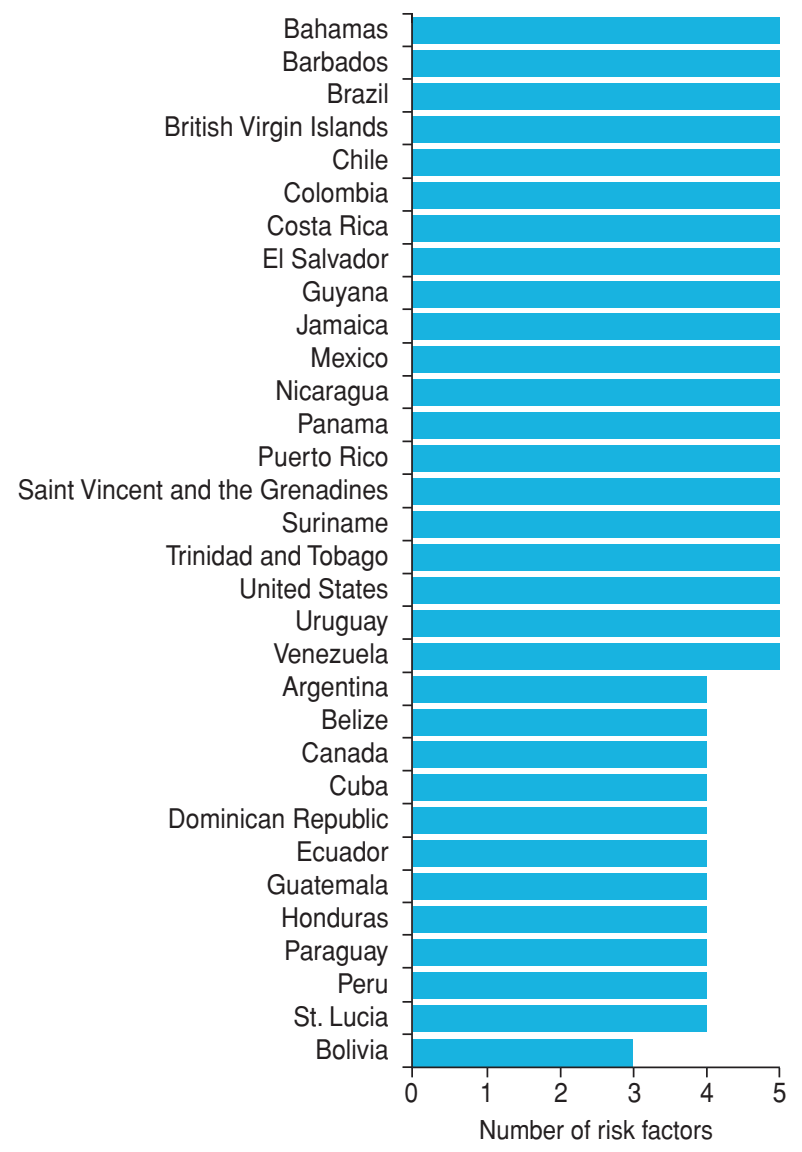

Comprehensive laws

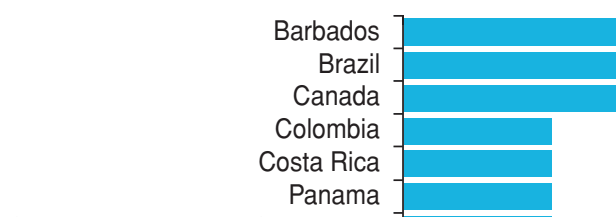

Saint Vincent and the Grenadines Trinidad and Tobago Venezuela British Virgin Islands Honduras Peru Suriname Argentina Bahamas Belize Bolivia Chile Cuba Dominican Republic Ecuador El Salvador Guatemala Guyana Jamaica Mexico Nicaragua Paraguay Puerto Rico St. Lucia United States Uruguay

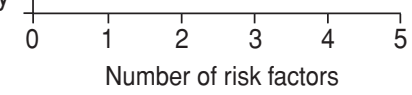

FIGURE 2. Level of progression in five risk factors under study in the region of the Americas, 2008

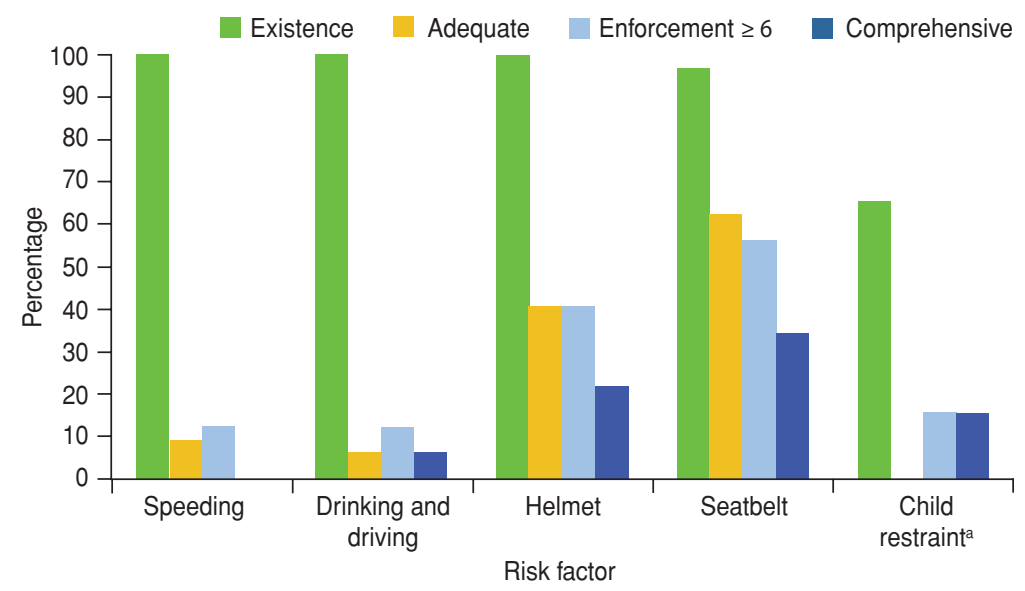

${ }^{a}$ Adequacy of child restraint laws was not evaluated.

5.1. Comprehensive laws existed in only $21.9 \%$ of the countries: Barbados, Brazil, Canada, Colombia, Saint Vincent and the Grenadines, Trinidad and Tobago, and Venezuela.

\section{Seatbelts}

Bolivia was the only country that lacked any type of legislation aimed to address seatbelt use. The rest of the countries have national or subnational legislation on the obligatory nature of seatbelt use. Although this risk factor could be seen as the most targeted of the five risk factors under study, seatbelt use is obligatory for all passengers in only $63 \%$ of the countries. This issue was not explored in the United States because questions about the characteristics of legislation and level of enforcement were not applied for countries that do not have legislation at the national level. Although in Canada seatbelt legislation is set at the subnational level, those questions were answered.

Law enforcement was rated at 6 or higher by $56 \%$ of the countries. The average enforcement level was 5.8 in the countries with legislation, which is higher than the number for the other four risk factors. However, comprehensive laws were reported in only $34.4 \%$ of participating member states: Barbados, Brazil, the British Virgin Islands, Canada, Colombia, Costa Rica, Hondu- 
TABLE 2. Legislation, adequacy, and law enforcement for five behavioral risk factors for road traffic injuries in the region of the Americas, 2008

\begin{tabular}{|c|c|c|c|c|c|c|c|c|c|c|c|c|c|c|c|c|c|c|c|}
\hline \multirow[b]{2}{*}{ Country } & \multicolumn{4}{|c|}{ Speeding } & \multicolumn{4}{|c|}{ Drinking and driving } & \multicolumn{4}{|c|}{ Helmet } & \multicolumn{4}{|c|}{ Seatbelt } & \multicolumn{3}{|c|}{ Child restraint } \\
\hline & Exist. & Adeq. & Enf. & Comp. & Exist. & Adeq. & Enf. & Comp. & Exist. & Adeq. & Enf. & Comp. & Exist. & Adeq. & Enf. & Comp. & Exist. & Enf. & Comp. \\
\hline Argentina & Yes & No & 3 & No & Yes & No & 3 & No & Yes & No & 1 & No & Yes & Yes & 3 & No & Yes & NA & No \\
\hline Bahamas & Yes & No & 5 & No & Yes & No & 3 & No & Yes & Yes & 3 & No & Yes & Yes & 0 & No & Yes & 0 & No \\
\hline Barbados & Yes & No & 5 & No & Yes & No & 2 & No & Yes & Yes & 8 & Yes & Yes & Yes & 8 & Yes & Yes & 7 & Yes \\
\hline Belize & Yes & No & 1 & No & Yes & No & 3 & No & Yes & No & 3 & No & Yes & No & 4 & No & No & NA & No \\
\hline Bolivia & Yes & No & 3 & No & Yes & No & 4 & No & Yes & No & NA & No & No & No & NA & No & No & NA & No \\
\hline Brazil & Yes & NA & 6 & No & Yes & Yes & 6 & Yes & Yes & Yes & 7 & Yes & Yes & Yes & 6 & Yes & Yes & 4 & No \\
\hline British Virgin Islands & Yes & No & 6 & No & Yes & No & NA & No & Yes & No & 3 & No & Yes & Yes & 7 & Yes & Yes & 5 & \\
\hline Canada & Yes $^{a}$ & No & 5 & No & Yes & No & 4 & No & $Y_{e s}^{a}$ & Yes & 10 & Yes & $Y_{e s}^{a}$ & Yes & 7 & Yes & $Y_{e s}^{a}$ & 7 & Yes \\
\hline Chile & Yes & No & 5 & No & Yes & No & 3 & No & Yes & Yes & 3 & No & Yes & Yes & 5 & No & Yes & 4 & No \\
\hline Colombia & Yes & No & 4 & No & Yes & No & 5 & No & Yes & Yes & 6 & Yes & Yes & Yes & 7 & Yes & Yes & 3 & No \\
\hline Costa Rica & Yes & No & 6 & No & Yes & No & 6 & No & Yes & No & 6 & No & Yes & Yes & 7 & Yes & Yes & 6 & Yes \\
\hline Cuba & Yes & No & 5 & No & Yes & No & 4 & No & Yes & No & 8 & No & Yes & No & 8 & No & No & NA & No \\
\hline Dominican Republic & Yes & No & 2 & No & Yes & No & 2 & No & Yes & No & 2 & No & Yes & No & 6 & No & No & NA & No \\
\hline Ecuador & Yes & No & 3 & No & Yes & No & 5 & No & Yes & No & 2 & No & Yes & Yes & 3 & No & No & NA & No \\
\hline El Salvador & Yes & No & 4 & No & Yes & No & 5 & No & Yes & No & 6 & No & Yes & No & 7 & No & Yes & 0 & No \\
\hline Guatemala & Yes & NA & 3 & No & Yes $^{a}$ & No & NA & No & Yes & No & 3 & No & Yes & No & 5 & No & No & NA & No \\
\hline Guyana & Yes & No & 4 & No & Yes & No & NA & No & Yes & No & 5 & No & Yes & No & 7 & No & Yes & 0 & No \\
\hline Honduras & Yes & Yes & 3 & No & Yes & No & 4 & No & Yes & No & 5 & No & Yes & Yes & 7 & Yes & No & NA & No \\
\hline Jamaica & Yes & No & 3 & No & Yes & No & 2 & No & Yes & Yes & 3 & No & Yes & Yes & 5 & No & Yes & 4 & No \\
\hline Mexico & Yes & NA & 4 & No & Yes & No & 3 & No & Yes & Yes & 3 & No & Yes & Yes & 5 & No & Yes & 1 & No \\
\hline Nicaragua & Yes & Yes & 3 & No & Yes & No & 3 & No & Yes & No & 3 & No & Yes & No & 5 & No & Yes & 3 & No \\
\hline Panama & Yes & No & 7 & No & Yes & Yes & 6 & Yes & Yes & No & 9 & No & Yes & Yes & 7 & Yes & Yes & 3 & No \\
\hline Paraguay & Yes & Yes & 3 & No & $Y_{e s}^{a}$ & No & 3 & No & $Y_{e s}^{a}$ & No & 5 & No & Yes & Yes & 5 & No & No & NA & No \\
\hline Peru & Yes & No & 1 & No & Yes & No & 2 & No & Yes & Yes & 1 & No & Yes & Yes & 7 & Yes & No & NA & No \\
\hline Puerto Rico & Yes & No & NA & No & Yes & No & NA & No & Yes & Yes & NA & No & Yes & Yes & NA & No & Yes & NA & No \\
\hline Saint Lucia & Yes & No & 0 & No & Yes & No & 1 & No & Yes & No & 8 & No & Yes & No & 7 & No & No & NA & No \\
\hline Saint Vincent and the & & & & & & & & & & & & & & & & & & & \\
\hline Grenadines & Yes & No & 4 & No & Yes & No & NA & No & Yes & Yes & 9 & Yes & Yes & No & 9 & No & Yes & 6 & Yes \\
\hline Suriname & Yes & No & 5 & No & Yes & No & 4 & No & Yes & No & 7 & No & Yes & Yes & 7 & Yes & Yes & 3 & No \\
\hline Trinidad and Tobago & Yes & No & 3 & No & Yes & No & 2 & No & Yes & Yes & 9 & Yes & Yes & No & 6 & No & Yes & 6 & Yes \\
\hline United States & $Y_{e s}^{a}$ & NA & NA & No & $Y_{e s}^{a}$ & No & NA & No & $Y_{e s}^{a}$ & No & NA & No & $Y_{e s}^{a}$ & No & NA & No & $Y_{e s}^{a}$ & NA & No \\
\hline Uruguay & Yes & NA & NA & No & Yes & No & 1 & No & Yes & No & 5 & No & Yes & Yes & 3 & No & Yes & 1 & No \\
\hline Venezuela & Yes & No & 4 & No & Yes & No & 7 & No & Yes & Yes & 6 & Yes & Yes & Yes & 6 & Yes & Yes & 5 & No \\
\hline
\end{tabular}

Note: Exist.: existence, Adeq.: adequate, Enf.: enforcement level, Comp.: comprehensive, NA: not answered.

a Set at subnational level.

ras, Panama, Peru, Suriname, and Venezuela. This suggests the same problems observed for the rest of the risk factors: most countries still lack a comprehensive approach toward road safety.

\section{Child restraints}

More than $30 \%$ of the countries in the Americas reported not having legislation obligating the use of child restraint devices for young children in vehicles. For those that have legislation, enforcement of child restraint laws was low-on average 3.6-particularly when comparing it with legislation for the use of seatbelts and the use of helmets. Only 15.6\% of the countries valued enforcement of this law at a score of 6 or higher on a scale of 0-10. Since adequacy of laws on this risk factor was not evaluated, these five countries were considered to have comprehensive laws: Barbados, Canada,
Costa Rica, Saint Vincent and the Grenadines, and Trinidad and Tobago.

\section{DISCUSSION}

This effort constitutes the first approach to analyzing legislation on the main risk factors for RTIs in the Americas that uses a standardized methodology and covers the great majority of member countries of the $\mathrm{PAHO} / \mathrm{WHO}$ regional office, accounting for $99 \%$ of the people living in the region. However, previous work oriented and influenced the development of this study on road safety (7-9). It was possible to observe that in the past 5 years some progress has been made in the region. As an example, in five countries that previously requested the use of seatbelts only for people in the front seat, now use of seatbelts is mandatory for all individuals in all seats. This is the case in Chile, Co- lombia, Mexico, Panama, and Uruguay. In addition, during this period, BAC limits decreased in two countries in the region: in Brazil, from 0.06 to $0.02 \mathrm{~g} / \mathrm{dL}$; in El Salvador, from 0.1 to $0.05 \mathrm{~g} / \mathrm{dL}$. Future studies should be able to monitor the progression of the region toward a comprehensive approach to road safety.

According to the results of this study, the risk factor best addressed was seatbelt use, with $34 \%$ of participating countries having comprehensive legislation, followed by helmet use (22\%), use of child restraints $(16 \%)$, and drinking and driving $(6 \%)$. Speeding is the least addressed risk factor in participating countries, as no country reported having a comprehensive law. An overall assessment suggests that greater efforts should be made in the region to enforce existing laws for the five risk factors associated with RTIs. As has been recognized by WHO, addressing road safety in a comprehensive manner 
requires the involvement of multiple sectors through a common and coordinated multisectoral strategy on RTI prevention (3). In order to do this, a key element would be to allocate more financial resources, which still seems to be pending. Currently, only 8 of the 32 countries informed investment in road safety, and this fund appears not to be sufficient for the magnitude of the documented problem (4). Allocating money for road safety must include the built environment: roads where drivers can control speed, education campaigns to target awareness of reducing alcohol intake, and communicating the level of child mortality associated with lack of child restraints, to mention a few. The complexity of RTIs suggests that law enforcement alone is not enough and education and the improvement of safe road infrastructure should accompany application of the law.

This study has some limitations. The objective of the GRSS was not to corroborate or confirm the answers provided by respondents. As a result, this analysis assumes that all responses are correct, although responses might reflect a lack of accurate knowledge or familiarity with the topics explored among respondents. Although information was further validated by all governments, there is evidence that questions some of the answers provided by some participants (10). We also should be cautious with the information provided by all participants, as personal evaluation is subjective and context specific. In addition, it is important to consider that the use of child restraints might not be a priority in some countries of the region that have low motorization rates or where most road traffic victims are vulnerable road users, such as pedestrians. As discussed by some authors, not all health policies are beneficial for all road users and vulnerable road users might benefit the least (11). An illustrative example is the drinking and driving law, which focuses on car drivers, while the evidence shows that drunken motorcyclists and pedestrians have a high risk of being involved in a crash, but they are not included in the legislation (12). Thus, we can make the point that future work should address more legislation and health policies aimed at protecting those vulnerable road users in order to reduce the gap in terms of the burden of disease among groups of low socioeconomic status, who tend to be pedestrians (13).

Last, while law enforcement is essential for road safety, as highlighted by some authors (14), it is also important to improve existing laws. In this respect, international best practices and evaluated interventions should be copied and adapted to the specificities of the region. In at least two countries in the region (Colombia and Suriname), a new road user is appearing on the scene-motorcyclists (4) — which suggests two things: a probable reshaping of RTIs in the region and, consequently, the priorities of safety legislation and an opportunity to anticipate the problem by looking at international practices best developed in Southeast Asian countries.

\section{REFERENCES}

1. Peden MM. World report on road traffic injury prevention. Geneva: WHO; 2004.

2. Organización Panamericana de la Salud. Lesiones no intencionales. Legislación de América Latina sobre programas preventivos y responsabilidades. Colisión y atropello por vehículos, caídas, quemaduras y ahogamientos. 1a ed. Washington, D.C.: OPS; 2004.

3. World Health Organization. Global status report on road safety: time for action. Geneva: WHO; 2009.

4. Organización Panamericana de la Salud. Informe sobre el estado de la seguridad vial en la región de las Américas. 1a ed. Washington, D.C.: OPS; 2009.

5. World Health Organization. Methodology of the global status report on road safety. Geneva: WHO; 2009. Available from: http:// www.who.int/violence_injury_prevention/ road_safety_status/methodology/en/index. $\mathrm{html}$ Accessed 25 May 2012.

6. Stata Corporation. Stata 10.1. Stata Press publication. College Station, TX: Stata Press; 2009.

7. Acero-Velásquez $\mathrm{H}$, Concha-Eastman A. La seguridad vial un problema de política pública. Washington, D.C.: OPS; 2004.

8. Concha-Eastman A. Road safety in the Americas: an overview. Washington, D.C.: PAHO; 2004.

9. Planzer R. La seguridad vial en la región de América Latina y el Caribe. Situación actual y desafíos. Santiago de Chile: Comisión Económica para América Latina y el Caribe; 2005. (Report Number 102.)

10. Híjar M, Chandran A, Pérez-Núñez R, Lunnen JC, Rodríguez-Hernández J, Hyder AA. Quantifying the underestimated burden of road traffic mortality in Mexico: a com-

\section{Conclusions}

- Having laws aimed at addressing an important risk factor for RTIs is desirable, but it is only the first step.

- Having adequate laws is even better; laws should be based on what is known to be more effective.

- Enforcing laws is essential for road safety: improvement is still needed in the region.

\section{RECOMMENDATIONS}

Comprehensive laws are necessary to improve road safety for all road users, especially for the vulnerable ones. In setting speed limits, it is important to consider the type and function of the roads and streets, BAC limits should guarantee a reduction in driving under the influence of alcohol, and use of proper protection equipment should be required. Countries must think about law enforcement as a priority and ensure they have resources in their budgets for that purpose.

Acknowledgments. This analysis was enriched by comments received from Vilma P. Gawryszewski, Pierre Maurice, Jasline Flores, Margaret Herbert, Andrés Villaveces, José Ignacio Nazif Muñoz, Luis Roberto Escoto, and Maristela Monteiro. Opinions expressed in this work represent the point of view of the authors and not necessarily of their institutions. Financial support was provided by the Pan American Health Organization and Bloomberg's Philanthropies. parison of three approaches. Traffic Inj Prev. 2012;13(Suppl 1):5-10.

11. Ameratunga S, Híjar M, Norton R. Roadtraffic injuries: confronting disparities to address a global-health problem. Lancet. 2006;367(9521):1533-40.

12. Híjar M, Trostle JA. Traffic law enforcement and safety. Lancet. 2003;362(9386):833.

13. Nantulya VM, Reich MR. Equity dimensions of road traffic injuries in low- and middleincome countries. Inj Control Saf Promot. 2003;10(1-2):13-20.

14. Beltramino JC, Carrera E. El respeto a las normas de tránsito en la ciudad de Santa Fé, Argentina. Rev Panam Salud Publica. 2007;22(2):141-5.

Manuscript received on 22 June 2011. Revised version accepted for publication on 13 April 2012. 
RESUMEN La legislación sobre cinco de los principales factores de riesgo de sufrir lesiones causadas por el tránsito, así como el cumplimiento de la ley, son esenciales para forjar una cultura integral de seguridad vial. El análisis del nivel de progresión en el

\section{Legislación sobre seguridad vial en las Américas}

Palabras clave cumplimiento de la ley permite evaluar el estado de las regiones del mundo. Se llevó a cabo un análisis secundario de la encuesta Informe sobre la situación mundial de la seguridad vial: es hora de pasar a la acción, de 2009, para evaluar la legislación sobre cinco factores de riesgo (control de la velocidad, conducir bajo la influencia del alcohol, uso del casco al conducir motocicletas, uso de cinturones de seguridad y uso de sistemas de retención para niños) en las Américas. Las leyes se clasificaron según su nivel de progresión: la existencia de legislación, si la legislación es adecuada, un nivel de cumplimiento de la ley $\geq 6$ (en una escala de $0-10$ ) y si la ley se considera integral. Se realizó un análisis descriptivo. Todos los países tienen legislación nacional o subnacional al menos con respecto a uno de los cinco factores de riesgo; sin embargo, 63\% tienen leyes sobre los cinco factores de riesgo estudiados, y ninguno de ellos tiene leyes integrales para los cinco. La legislación sobre uso de cinturones de seguridad parece ser la de mayor cumplimiento, mientras que las leyes de exceso de velocidad parecen ser las que menos se cumplen. En la región hay esfuerzos positivos que deben reconocerse; sin embargo, existen diferentes etapas de progresión. El cumplimiento de la ley sigue siendo el principal tema por abordar. Las leyes deben basarse en datos de eficacia reconocida.

Legislación como asunto; accidentes de tránsito; cinturones de seguridad; sistemas de sujeción infantil; dispositivos de protección de la cabeza; Américas. 